\title{
Thyroxine-induced expression of pyroglutamyl peptidase II and inhibition of TSH release precedes suppression of TRH mRNA and requires type 2 deiodinase
}

\author{
Alessandro Marsili, Edith Sanchez ${ }^{1,+}$, Praful Singru ${ }^{1,+}$, John W Harney, Ann Marie Zavacki, \\ Ronald M Lechan ${ }^{1}$ and $\mathbf{P}$ R Larsen \\ Thyroid Section, Division of Endocrinology, Diabetes and Hypertension, Brigham and Women's Hospital and Harvard Medical School, Harvard Institutes of \\ Medicine, Room 644, 77 Avenue Louis Pasteur, Boston, Massachusetts 02115, USA \\ ${ }^{1}$ Division of Endocrinology, Diabetes and Metabolism, Department of Medicine, Tufts Medical Center, Boston, Massachusetts 02111, USA \\ (Correspondence should be addressed to P R Larsen; Email: plarsen@partners.org) \\ ${ }^{\dagger}$ E Sanchez is now at Direccion de Investigaciones en Neurociencias, Instituto Nacional de Psiquiatria Ramon de la Fuente Muniz, Mexico D.F.14370, Mexico \\ ${ }^{\ddagger} \mathrm{P}$ Singru is now at School of Biological Sciences, National Institute of Science Education and Research (NISER), Institute of Physics Campus, Sachivalaya Marg, \\ PO: Sainik School, Bhubaneswar 751 005, Orissa, India
}

\begin{abstract}
Suppression of TSH release from the hypothyroid thyrotrophs is one of the most rapid effects of $3,3^{\prime}, 5^{\prime}$-triiodothyronine $\left(\mathrm{T}_{3}\right)$ or thyroxine $\left(\mathrm{T}_{4}\right)$. It is initiated within an hour, precedes the decrease in TSH $\beta$ mRNA inhibition and is blocked by inhibitors of mRNA or protein synthesis. TSH elevation in primary hypothyroidism requires both the loss of feedback inhibition by thyroid hormone in the thyrotrophs and the positive effects of TRH. Another event in this feedback regulation may be the thyroid hormone-mediated induction of the TRH-inactivating pyroglutamyl peptidase II (PPII) in the hypothalamic tanycytes. This study compared the chronology of the acute effects of $\mathrm{T}_{3}$ or $\mathrm{T}_{4}$ on $\mathrm{TSH}$ suppression, TRH mRNA in the hypothalamic paraventricular nucleus (PVN), and the induction of tanycyte PPII.
\end{abstract}

In wild-type mice, $\mathrm{T}_{3}$ or $\mathrm{T}_{4}$ caused a $50 \%$ decrease in serum $\mathrm{TSH}$ in hypothyroid mice by $5 \mathrm{~h}$. There was no change in TRH mRNA in PVN over this interval, but there was a significant increase in PPII mRNA in the tanycytes. In mice with genetic inactivation of the type 2 iodothyronine deiodinase, $\mathrm{T}_{3}$ decreased serum TSH and increased PPII mRNA levels, while $\mathrm{T}_{4}$-treatment was ineffective. We conclude that the rapid suppression of $\mathrm{TSH}$ in the hypothyroid mouse by $\mathrm{T}_{3}$ occurs prior to a decrease in TRH mRNA though TRH inactivation may be occurring in the median eminence through the rapid induction of tanycyte PPII. The effect of $T_{4}$, but not $T_{3}$, requires the type 2 iodothyronine deiodinase.

Journal of Endocrinology (2011) 211, 73-78

\section{Introduction}

The feedback regulation of $\mathrm{TSH}$ secretion by thyroid hormones is mediated by the binding of $3,3^{\prime}, 5^{\prime}$-triiodothyronine $\left(\mathrm{T}_{3}\right)$ to the TR $\beta 2$ receptor in the pituitary and hypothalamus (Chiamolera \& Wondisford 2009). The acute suppression of TSH release from the pituitary is initiated within $30 \mathrm{~min}$ of the injection of thyroxine $\left(\mathrm{T}_{4}\right)$ or $\mathrm{T}_{3}$ to the hypothyroid rat and the degree of suppression parallels that of the saturation of the nuclear $\mathrm{T}_{3}$ receptors in the pituitary (Silva \& Larsen 1977, Larsen et al. 1981). This response is blocked by inhibitors of mRNA or protein synthesis, suggesting that there may be induction or suppression of specific proteins that are required for this effect (Bowers et al. 1968a,b, Vale et al. 1968). The decrease in circulating TSH in these models occurs well before suppression of the synthesis of TSH $\beta$ mRNA and, in fact, studies have shown that in the early phases of the response, there is an increase in pituitary TSH content, suggesting that synthesis proceeds for some period of time in association with inhibition of release of the hormone (Silva \& Larsen 1978, Shupnik et al. 1989). While most studies have focused on events in the pituitary, it is clear that positive regulation of TSH by TRH is also required for TSH elevation during hypothyroidism, indicating that this is not simply due to the absence of negative feedback regulation on the thyrotroph TSH (Nikrodhanond et al. 2006).

It is well known that the conversion of $\mathrm{T}_{4}$ to $\mathrm{T}_{3}$ by the type 2 deiodinase (D2) is required for suppression of TSH at the pituitary level (Larsen et al. 1979). The requisite degree of saturation of the thyrotroph nuclear $\mathrm{T}_{3}$ receptors requires both circulating $\mathrm{T}_{3}$ and $\mathrm{D} 2$-mediated conversion of intracellular $\mathrm{T}_{4}$. The normal feedback regulation of $T R H$ mRNA synthesis similarly requires both circulating $\mathrm{T}_{3}$ and that derived from D2-mediated $T_{4}$ to $T_{3}$ conversion 
(Kakucska et al. 1992, Lechan \& Fekete 2005). Since there is no D2 mRNA in the parvocellular region of the hypothalamic paraventricular nucleus (PVN) where hypophysiotropic TRH is synthesized, it has been proposed that the D2 highly expressed in tanycytes of the mediobasal hypothalamus may provide $\mathrm{T}_{3}$ to $\mathrm{TRH}$-producing neurons through extensive cell to cell interactions (Riskind et al. 1987, Tu et al. 1997, Fekete \& Lechan 2007). Recent evidence has suggested that inactivation of TRH in the median eminence by pyroglutamyl peptidase II (PPII), a membrane-bound, highly specific TRH peptidase expressed in the tanycytes (Charli et al. 1998, Heuer et al. 2000), contributes to central regulation of TSH secretion (Sanchez et al. 2009). PPII is also expressed in lactotrophs and somatotrophs in the rat pituitary but not in thyrotrophs (Heuer et al. 1998, Cruz et al. 2008), indicating that pituitary PPII may not be involved in TSH regulation. As PPII synthesis is a $T_{3}$-dependent process, with PPII mRNA being induced in the median eminence within a few hours of exposure to $\mathrm{T}_{3}$ or $\mathrm{T}_{4}$ (Sanchez et al. 2009), it suggests that its acute effects to inactivate TRH are localized in this region.

The D2 knockout mouse is resistant to the feedback effects of $\mathrm{T}_{4}$ on pituitary TSH release in both the euthyroid and the hypothyroid states (Schneider et al. 2001, Christoffolete et al. 2007). In this study, we used this model to analyze the chronological correlations between the inhibition of TSH release in response to $T_{4}$ or $T_{3}$ in intact animals with the induction of PPII mRNA in the tanycytes as opposed to preproTRH mRNA in the PVN. Our results indicate that the increase in PPII mRNA occurs before any reduction in intact preproTRH mRNA, suggesting that an increase in PPII with its consequent inactivation of TRH could play a role in the acute suppression of TSH release by $\mathrm{T}_{3}$ or $\mathrm{T}_{4}$.

\section{Materials and Methods}

\section{Animals}

All animal experimental protocols were approved by the Animal Research Committee of Harvard Medical School. C57BL/6J mice were purchased from The Jackson Laboratories (Bar Harbor, ME, USA). D2KO/C57Bl/6J are as described previously (Schneider et al. 2001). All animals were maintained under $12 \mathrm{~h}$ light: $12 \mathrm{~h}$ darkness cycle and the standard animal facility temperature and humidity.

\section{Hypothyroidism induction and experimental protocol}

Mice were made hypothyroid by placing them on drinking water containing $0 \cdot 1 \% \mathrm{MMI}$ (Sigma) and $1 \% \mathrm{KClO}_{4}$ (Fisher Scientific Co., Pittsburgh, PA, USA; $\left.\mathrm{MMI} / \mathrm{ClO}_{4}\right)$, as described previously (Marsili et al. 2010). On the day of the experiment, a serum sample was obtained from the tail for TSH measurement. Immediately after, 6n-propylthiouracil (PTU; $2 \mathrm{mg} /$ animal) was administered intraperitoneally to block D1 activity. One hour later, D2KO and WT mice were subdivided into three groups, each mouse receiving a single i.p. injection of $\mathrm{T}_{4}(3 \mu \mathrm{g} / 100 \mathrm{~g}$ body weight $), \mathrm{T}_{3}$ $(1 \cdot 2 \mu \mathrm{g} / 100 \mathrm{~g}$ body weight), or vehicle (PBS). Five hours after the hormone/vehicle administration, the mice were killed with an isoflurane overdose and blood collected via cardiac puncture.

\section{Tissue processing}

Animals were overdosed with pentobarbital $(50 \mathrm{mg} / \mathrm{kg}$; Ovation Pharmaceuticals, Inc., Deerfield, IL, USA) and perfused transcardially with $0 \cdot 01 \mathrm{M}$ PBS $(\mathrm{pH} 7 \cdot 4)$ containing $15000 \mathrm{U} / 1$ heparin sulfate, followed by 4\% paraformaldehyde in PBS. The brains were removed and postfixed by immersion in the same fixative for $2 \mathrm{~h}$ at room temperature. Tissue blocks containing the hypothalamus were cryoprotected in $25 \%$ sucrose/PBS at $4{ }^{\circ} \mathrm{C}$ overnight and then snap frozen on dry ice. Serial $18 \mu \mathrm{m}$-thick coronal sections through the rostrocaudal extent of PVN and median eminence were cut on a cryostat (Leica CM3050 S; Leica Microsystems, Nussloch GmbH, Wetzlar, Germany) and adhered to Superfrost/Plus glass slides (Fisher Scientific Co.) to obtain four sets of slides, each set containing every fourth section through the PVN or median eminence. The tissue sections were desiccated overnight at $42{ }^{\circ} \mathrm{C}$ and stored at $-80{ }^{\circ} \mathrm{C}$ until prepared for in situ hybridization histochemistry.

\section{In situ hybridization histochemistry}

Every fourth section through the PVN or median eminence was hybridized with an $800 \mathrm{bp}$ single-stranded [ ${ }^{35}$ S]UTPlabeled cRNA probe complementary to the entire coding region of the mouse TRH gene, or $644 \mathrm{bp}$ single-stranded $\left[{ }^{35} \mathrm{~S}\right] \mathrm{UTP}-\mathrm{labeled}$ cRNA probe complementary to the coding region of rat PPII (nucleotides 129-773), respectively, as described previously (Sanchez et al. 2009, Kadar et al. 2010).

Hybridizations were performed under plastic coverslips in a buffer containing $50 \%$ formamide, a twofold concentration of standard sodium citrate $(2 \times$ saline sodium citrate), $10 \%$ dextran sulfate, $0 \cdot 25 \%$ BSA, $0 \cdot 25 \%$ Ficoll 400, 0.25\% polyvinylpyrrolidone $360,250 \mathrm{mM}$ Tris ( $\mathrm{pH} 8 \cdot 0$ ), $0 \cdot 5 \%$ SDS,

Table 1 Serum thyroid hormone concentrations in hypothyroid WT and D2KO mice $5 \mathrm{~h}$ after hormone or vehicle injection (mean \pm S.E.M.; $n=5-7$ per group)

\begin{tabular}{|c|c|c|c|c|}
\hline & \multicolumn{2}{|c|}{ Serum $T_{3}(n g / m l)$} & \multicolumn{2}{|c|}{ Serum $T_{4}(\mu \mathrm{g} / \mathrm{dl})$} \\
\hline & WT & $\mathrm{D} 2 \mathrm{KO}$ & WT & $\mathrm{D} 2 \mathrm{KO}$ \\
\hline \multicolumn{5}{|l|}{ Treatment } \\
\hline Vehicle & $0 \cdot 3 \pm 0 \cdot 1$ & $0 \cdot 2 \pm 0 \cdot 1$ & $1 \cdot 1 \pm 0 \cdot 2$ & $0 \cdot 9 \pm 0 \cdot 1$ \\
\hline $\mathrm{T}_{3}(1 \cdot 2 \mu \mathrm{g}$ i.p. $/ 100 \mathrm{~g} \mathrm{bw})$ & $19 \cdot 4 \pm 0 \cdot 4^{*}$ & $16 \cdot 3 \pm 3 \cdot 0 *$ & $1 \cdot 2 \pm 0 \cdot 2$ & $0 \cdot 9 \pm 0 \cdot 1$ \\
\hline $\mathrm{T}_{4}(3 \mu \mathrm{g}$ i.p. $/ 100 \mathrm{~g}$ bw) & $0 \cdot 6 \pm 0 \cdot 1$ & $0 \cdot 4 \pm 0 \cdot 2$ & $13 \cdot 8 \pm 2 \cdot 5^{*}$ & $11 \cdot 5 \pm 2 \cdot 5^{*}$ \\
\hline
\end{tabular}

$* P<0 \cdot 001$ versus vehicle. 


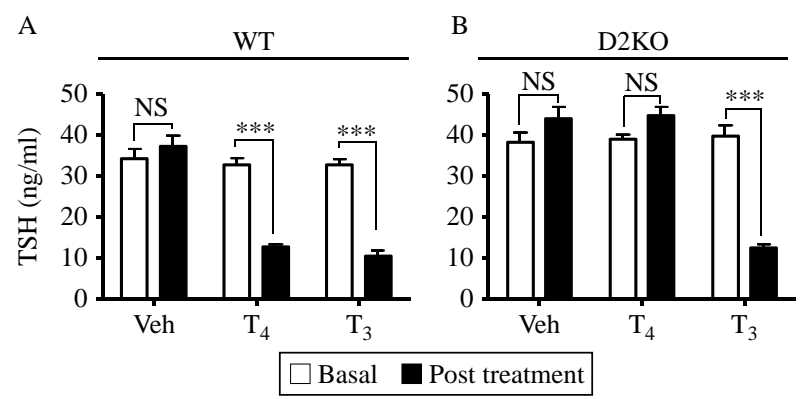

Figure 1 Effect of $T_{3}$ and $T_{4}$ on serum TSH in hypothyroid WT and D2KO mice. TSH values were measured before and $5 \mathrm{~h}$ after i.p. administration of vehicle, $\mathrm{T}_{4}\left(3 \mu \mathrm{g} / 100 \mathrm{~g}\right.$ body weight) or $\mathrm{T}_{3}$ $1 \cdot 2 \mu \mathrm{g} / 100 \mathrm{~g}$ body weight. All animals received $2 \mathrm{mg}$ PTU i.p. $1 \mathrm{~h}$ before hormone or vehicle administration. (A) Wild-type mice; (B) D2KO mice. Data are mean \pm s.E.M. of five to seven animals per group; $* * * P<0 \cdot 001$ for difference from pre-injection; NS, not significant.

$250 \mu \mathrm{g} / \mathrm{ml}$ denatured salmon sperm DNA, and $5 \times 10^{5}$ c.p.m. of the radiolabeled probe for $16 \mathrm{~h}$ at $55^{\circ} \mathrm{C}$. Slides were dipped into Kodak NTB autoradiography emulsion (Eastman Kodak) diluted 1:1 in distilled water and the autoradiograms developed after $3 \mathrm{~d}$ of exposure for TRH mRNA or $30 \mathrm{~d}$ of exposure for PPII mRNA at $4{ }^{\circ} \mathrm{C}$. The specificity of hybridization was confirmed using sense probes, which resulted in the total absence of specific hybridization signal in the hypothalamus.

\section{Image analysis}

Slides were visualized with an Axioplan 2 imaging microscope (Carl Zeiss Microimaging, Inc., Thornwood, NY, USA) under dark-field illumination using a COHU 4912 video camera (COHU, Inc., San Diego, CA, USA), and the images analyzed with a Macintosh G4 computer using Scion Image software (National Institutes of Health, Bethesda, MD, USA). Background was removed by thresholding the image and integrated density values (density $X$ area) of the hybridized regions were measured in rostrocaudal serial sections through the PVN or median eminence in one set of slides for each animal. Nonlinearity of radioactivity in the emulsion was evaluated by comparing density values with a calibration curve created from autoradiograms of known dilutions of the radiolabeled probes, immobilized on glass slides in $1.5 \%$ gelatin, fixed with $4 \%$ paraformaldehyde, and exposed and developed simultaneously with the in situ hybridization autoradiograms.

\section{Serum $T_{4}, T_{3}$, TSH measurement}

All hormones were measured by RIA after collecting blood from the tail vein. Serum $\mathrm{T}_{4}$ and $\mathrm{T}_{3}$ were measured using the COAT-A-COUNT total $\mathrm{T}_{4}$ and $\mathrm{T}_{3}$ kit (DPC, Los Angeles, CA, USA), following the manufacturer's instructions, with mouse standard curves prepared in charcoal-stripped ( $\mathrm{T}_{4}$ and $\mathrm{T}_{3}$ deficient) mouse serum as described previously (Christoffolete et al. 2007, Marsili et al. 2010). TSH was determined using the rat TSH RIA from Alpco Diagnostic (Salem, NH, USA). All values fell within the linear range of a curve generated by the serial dilution of sample dilution buffer. The normal range for $T_{4}$ was $1.61 \pm 0.17$ and $2.79 \pm 0.32 \mu \mathrm{g} / \mathrm{dl}$ for $\mathrm{WT}$ and $\mathrm{D} 2 \mathrm{KO}$ respectively. The normal range for $\mathrm{T}_{3}$ was $0.76 \pm 0.07$ and $0.77 \pm 0.06 \mathrm{ng} / \mathrm{ml}$ for $\mathrm{WT}$ and $\mathrm{D} 2 \mathrm{KO}$ respectively (Christoffolete et al. 2007). TSH concentrations (ng/ml) were determined by extrapolating from the intercept of the high TSH mouse serum with the purified rat TSH standard curve supplied by the manufacturer, after correction for the difference of the nonspecific binding obtained with serum versus the nonspecific binding obtained with the assay
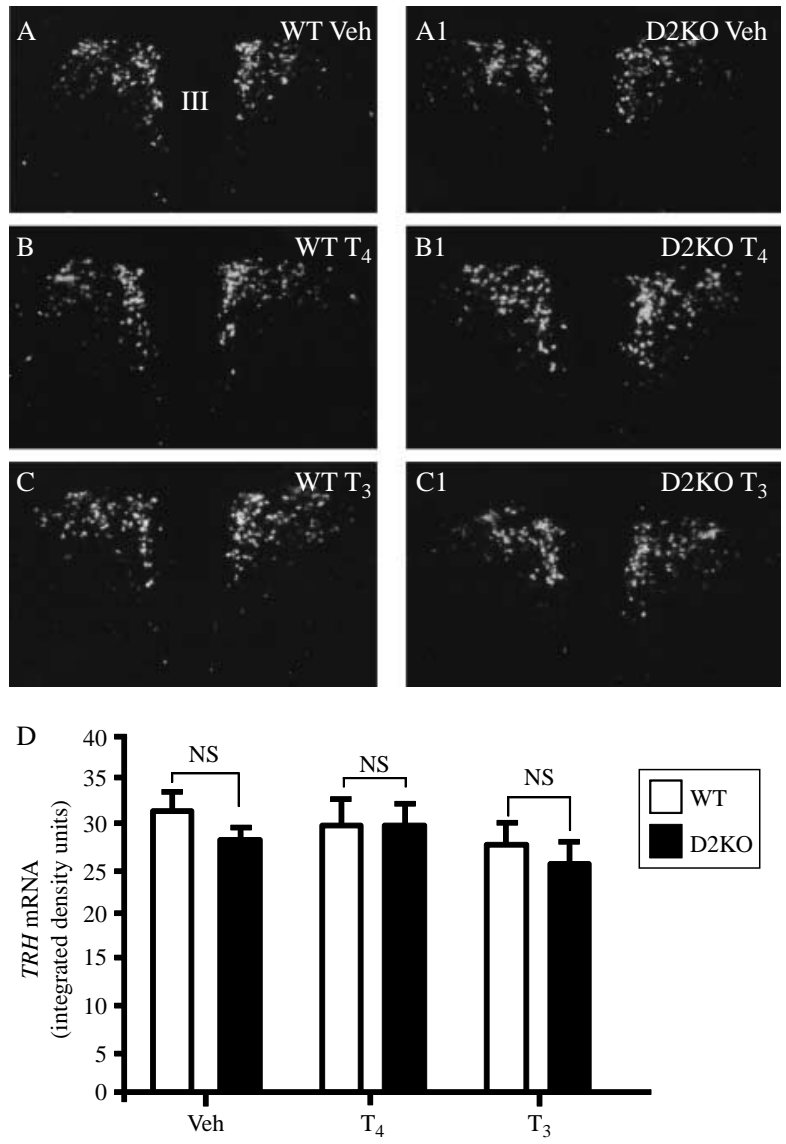

Figure 2 Absence of an acute response of $T R H$ mRNA $5 \mathrm{~h}$ after $\mathrm{T}_{3}$ and $\mathrm{T}_{4}$ treatment in hypothyroid WT and D2KO mice. (A) Dark-field illumination photomicrographs of TRH mRNA in the medial parvocellular subdivision of the hypothalamic paraventricular nucleus (PVN) in hypothyroid WT (A-C) and D2KO mice (A1-C1) $5 \mathrm{~h}$ after i.p. administration of vehicle, $\mathrm{T}_{4}(3 \mu \mathrm{g} / 100 \mathrm{~g}$ body weight $)$ or $T_{3}(1 \cdot 2 \mu \mathrm{g} / 100 \mathrm{~g}$ body weight). (D) Graph represents the densitometric analyses of the in situ hybridization autoradiograms. Data are analyzed by two-way ANOVA after Bonferroni correction. NS, not significant. Data are mean \pm s.E.M. of five to seven mice per group. III, third ventricle. 
buffer (Pohlenz et al. 1999). TSH concentrations were $4 \cdot 04$ \pm 0.67 (range from $3 \cdot 32$ to $4 \cdot 93$ ) and $35 \cdot 7 \pm 5 \cdot 2$ (range from $27 \cdot 5$ to $47 \cdot 8$ ) ng rat equivalent/ $\mathrm{ml}$ of rat equivalent serum in euthyroid and hypothyroid male mice respectively.

\section{Statistical analysis}

Results are presented as mean \pm s.E.M. When only two groups were analyzed, statistical significance was determined using an unpaired Student's $t$-test. Two-way ANOVA followed by Bonferroni correction using Prism 4 software (GraphPad Software, Inc., San Diego, CA, USA) was used to compare the effects of three different treatments on two genotypes (WT and D2KO). $P$ values $<0.05$ were considered statistically significant.

\section{Results}

Both wild-type and D2KO mice were markedly hypothyroid after 5 weeks of treatment with antithyroid drugs, as confirmed by measurements of $\mathrm{T}_{3}, \mathrm{~T}_{4}$, and $\mathrm{TSH}$ (Table 1 and Fig. 1). Serum TSH values were markedly elevated in vehicle-treated mice in both groups in the range of $30-40 \mathrm{ng} / \mathrm{ml}$, about tenfold the normal value (Fig. 1). $\mathrm{T}_{3}$ caused a marked increase in serum $\mathrm{T}_{3} 5 \mathrm{~h}$ after injection in both WT and D2KO mice (Table 1). Serum $\mathrm{T}_{4}$ concentrations were also three- to four-fold the normal level in both wild-type and $\mathrm{D} 2 \mathrm{KO}$ mice after the $\mathrm{T}_{4}$ injection, with no difference between the two genotypes. Since all animals had received PTU to block D1-mediated $T_{4}$ to $T_{3}$ conversion, it was not surprising that the serum $T_{3}$ in the $\mathrm{T}_{4}$-treated mice was not significantly different from vehicle-treated mice. Injection of vehicle and manipulation of the animals caused no change in the serum TSH values (Fig. 1). $\mathrm{T}_{4}$ caused an $\sim 60 \%$ decrease in TSH in the wildtype animals $(P<0 \cdot 001)$ but had no effect in the D2KO mice (Fig. 1). On the other hand, both $\mathrm{WT}$ and $\mathrm{D} 2 \mathrm{KO}$ animals had an $\sim 70-80 \%$ decrease in TSH after injection of $\mathrm{T}_{3}(P<0 \cdot 001)$.

To determine whether the $\mathrm{T}_{3^{-}}$or $\mathrm{T}_{4}$-induced acute decrease in TSH involved suppression of TRH mRNA, we performed in situ hybridization examination of preproTRH mRNA expression in the PVN of the same mice. In all animals, the TRH mRNA was markedly increased over that in euthyroid mice, as a consequence of their hypothyroidism (Kadar et al. 2010). Despite the significant decrease in TSH in all mice receiving $T_{3}$ and in the $W T$ mice receiving $T_{4}$, there was no significant change in the integrated density values of the TRH mRNA in the thyroid hormone-treated groups (Fig. 2).

Because it has been previously shown that there is an increase in the PPII mRNA in hypothalamus 4-7 h after a single dose of $\mathrm{T}_{3}$ or $\mathrm{T}_{4}$ (Sanchez et al. 2009), we examined the mediobasal hypothalamus for changes in PPII mRNA.
In vehicle-treated WT animals, PPII mRNA was barely detectable in tanycytes lining the floor of the third ventricle but increased significantly in WT mice treated with $\mathrm{T}_{4}$ (Fig. 3). No change was observed in the $\mathrm{T}_{4}$-treated $\mathrm{D} 2 \mathrm{KO}$ animals (Fig. 3). Thus, the tanycytes in the median eminence require D2-mediated $T_{4}$ to $T_{3}$ conversion for induction of PPII transcription, and this occurs within a $5 \mathrm{~h}$ interval. As expected, PPII mRNA in both WT and D2KO mice responded modestly to $T_{3}$ (Fig. 3) with a significant increase in PPII $(P<0 \cdot 05)$, which was, however, less that that in the $\mathrm{T}_{4}$-treated WT animals $(P<0 \cdot 01)$.
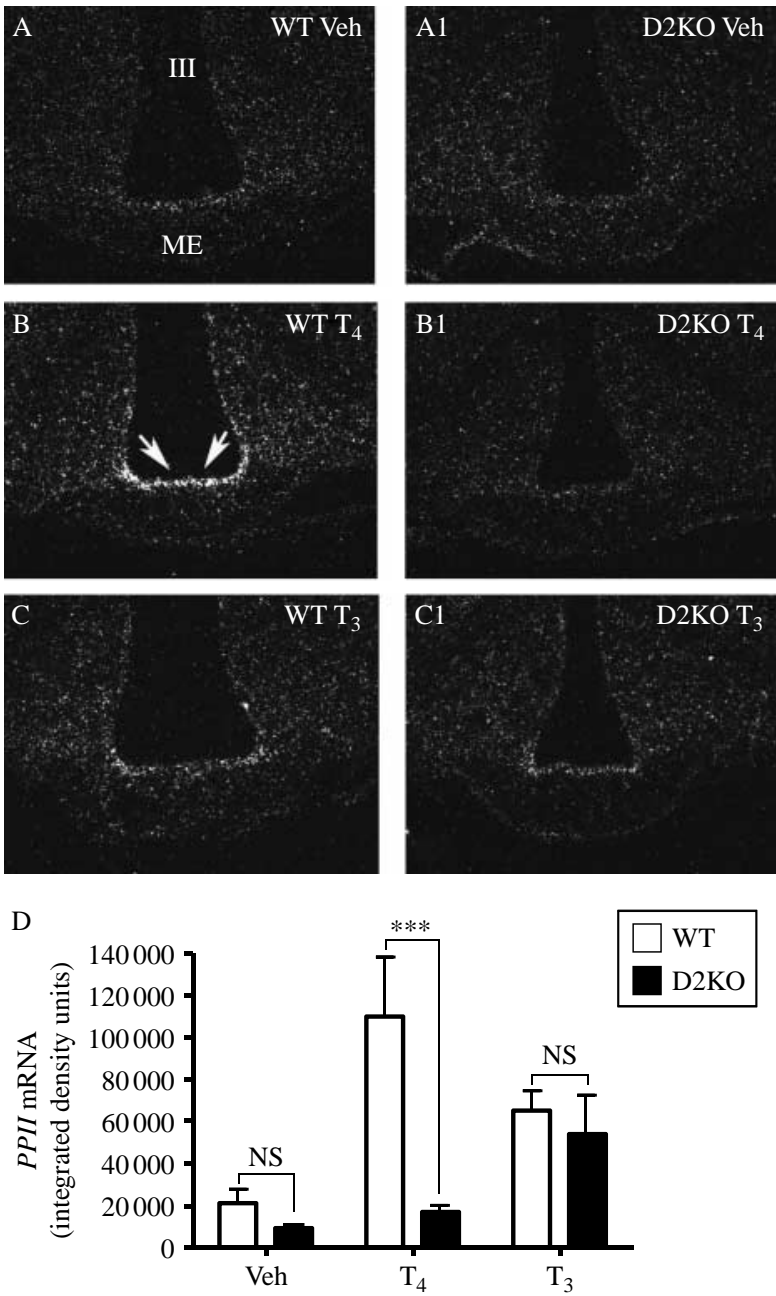

Figure 3 The acute increase in PPII mRNA induced by $\mathrm{T}_{4}$, but not $\mathrm{T}_{3}$, is absent in D2KO mice. Dark-field illumination photomicrographs of PPII mRNA (arrows) in tanycytes lining the floor of the third ventricle (III) at the level of the median eminence (ME) in hypothyroid WT (A-C) and D2KO (A1-C1) $5 \mathrm{~h}$ after administration of vehicle, $\mathrm{T}_{4}\left(3 \mu \mathrm{g} / 100 \mathrm{~g}\right.$ body weight) or $\mathrm{T}_{3}(1 \cdot 2 \mu \mathrm{g} / 100 \mathrm{~g}$ body weight. (D) Graph represents the densitometric analyses of the in situ hybridization autoradiograms. Data were analyzed by twoway ANOVA after Bonferroni correction. ${ }^{* *} P<0 \cdot 001$; NS, not significant. Data are mean \pm S.E.M. of five to seven mice per group. 


\section{Discussion}

These studies confirm a previous report that administration of both $\mathrm{T}_{4}$ and $\mathrm{T}_{3}$ results in $>50 \%$ suppression of TSH in hypothyroid mice within $5 \mathrm{~h}$ and that the response to $\mathrm{T}_{4}$, but not to $\mathrm{T}_{3}$, is absent in D2KO mice (Schneider et al. 2001). This pattern is similar to the results found earlier in hypothyroid rats in which the degree of acute suppression of TSH release was shown to parallel the occupancy of the pituitary nuclear $T_{3}$ receptors (Silva \& Larsen 1977, 1978), an effect blocked by inhibition of D2 with iopanoic acid (Larsen et al. 1979). A decrease in TSH secretion from T $\alpha$ T1 mouse thyrotroph cells by $\mathrm{T}_{4}$ also requires $\mathrm{D} 2$-mediated $\mathrm{T}_{4}$ to $\mathrm{T}_{3}$ conversion but does not require TRH (Christoffolete et al. 2007). Thus, some or all of the acute effects of $T_{4}$ may be due to a direct interaction of the intracellular $\mathrm{T}_{3}$ produced by $\mathrm{D} 2$ in the thyrotrophs.

In addition, TRH synthesis is also negatively regulated by $\mathrm{T}_{3}$ (Segerson et al. 1987). While a decrease in prepro TRH gene transcription by $\mathrm{T}_{3}$ has been demonstrated within $5 \mathrm{~h}$ using an intronic probe, we found no change in the TRH mRNA content of the hypothalamus over this time period (Fig. 2; Sugrue et al. 2010). This argues that a decrease in TRH synthesis is not required for the rapid inhibition of TSH release by thyroid hormone in the hypothyroid mouse but does not eliminate the possibility that an acute suppression of TRH also play a role in this response.

Recent studies have identified high expression of the TRH-inactivating PPII in the tanycytes in the floor of the third ventricle. This metalloprotease is encoded by a positively $\mathrm{T}_{3}$-responsive gene, and its mRNA increases as early as $4 \mathrm{~h}$ within the cell bodies of the tanycyte population (Sanchez et al. 2009). There is a close association between tanycyte end foot processes and preproTRH-containing axon terminals in the median eminence, suggesting a potential inactivation of TRH at this site. Our experiments revealed a significant increase in PPII mRNA within $5 \mathrm{~h}$ of $\mathrm{T}_{3}$ treatment, with an even more potent effect of $\mathrm{T}_{4}$ at this dosage in WT mice, while PPII expression was unchanged after $\mathrm{T}_{4}$ administration in D2KO mice. These results indicate that D2mediated $T_{4}$ to $T_{3}$ conversion, presumably in tanycytes, is required for the rapid induction by $\mathrm{T}_{4}$ of PPII mRNA in hypothyroid mice. Of particular importance, however, is the observation that PPII inhibition increases the TSH response to cold exposure or TRH (Sanchez et al. 2009), indicating that PPII plays a role in increasing endogenous TSH release. It is conceivable, therefore, that the acute fall of TSH in hypothyroid animals treated with thyroid hormone could also involve a reduction in the TRH supply to thyrotrophs as a result of its degradation in the median eminence by the rapid $\mathrm{T}_{3}$-mediated induction of tanycyte PPII. This may supplement the effect of $\mathrm{T}_{3}$-induced suppression of TSH release in the thyrotroph per se through an as yet undefined mechanism.

We cannot exclude the possibility that increase in somatostatin or dopamine could be involved in this acute response. These agents are known to inhibit TSH release and could be stimulated by $\mathrm{T}_{3}$. However, in vitro effects of these agents require several days rather than hours of exposure (Foord et al. 1984, Levy et al. 1992, Tam et al. 1996). Given the previously demonstrated blockade of this $\mathrm{T}_{3}$ effect by protein synthesis or gene transcription inhibitors (Bowers et al. 1968a,b, Vale et al. 1968), and the correlation between $T_{3}$ receptor occupancy and the magnitude of the effect in earlier studies (Silva \& Larsen 1977, 1978), a rapid gene transcriptional effect in thyrotrophs and perhaps in the tanycytes seems to be a more attractive hypothesis for the acute action of $\mathrm{T}_{3}$ in this system.

\section{Declaration of interest}

The authors declare that there is no conflict of interest that could be perceived as prejudicing the impartiality of the research reported.

\section{Funding}

This work was supported by the National Institutes of Health Grants DK36256 and T32DK007529 to P R L and DK37021 to R M L. A M was partially supported by a fellowship stipend from Department of Endocrinology and Kidney, University Hospital of Pisa, Italy.

\section{References}

Bowers CY, Lee KL \& Schally AV 1968a Effect of actinomycin D on hormones that control the release of thyrotropin from the anterior pituitary glands of mice. Endocrinology 82 303-310. (doi:10.1210/endo-82-2-303)

Bowers CY, Lee KL \& Schally AV 1968b A study on the interaction of the thyrotropin-releasing factor and L-triiodothyronine: effects of puromycin and cycloheximide. Endocrinology 82 75-82. (doi:10.1210/endo-82-1-75)

Charli JL, Vargas MA, Cisneros M, de Gortari P, Baeza MA, Jasso P, Bourdais J, Perez L, Uribe RM \& Joseph-Bravo P 1998 TRH inactivation in the extracellular compartment: role of pyroglutamyl peptidase II. Neurobiology 6 45-57.

Chiamolera MI \& Wondisford FE 2009 Minireview: thyrotropin-releasing hormone and the thyroid hormone feedback mechanism. Endocrinology $\mathbf{1 5 0}$ 1091-1096. (doi:10.1210/en.2008-1795)

Christoffolete MA, Arrojo e Drigo R, Gazoni F, Tente SM, Goncalves V, Amorim BS, Larsen PR, Bianco AC \& Zavacki AM 2007 Mice with impaired extrathyroidal thyroxine to $3,5,3^{\prime}$-triiodothyronine conversion maintain normal serum $3,5,3^{\prime}$-triiodothyronine concentrations. Endocrinology 148 954-960. (doi:10.1210/en.2006-1042)

Cruz R, Vargas MA, Uribe RM, Pascual I, Lazcano I, Yiotakis A, Matziari M, Joseph-Bravo P \& Charli JL 2008 Anterior pituitary pyroglutamyl peptidase II activity controls TRH-induced prolactin release. Peptides 29 1953-1964. (doi:10.1016/j.peptides.2008.07.011)

Fekete C \& Lechan RM 2007 Negative feedback regulation of hypophysiotropic thyrotropin-releasing hormone (TRH) synthesizing neurons: role of neuronal afferents and type 2 deiodinase. Frontiers in Neuroendocrinology 28 97-114. (doi:10.1016/j.yfrne.2007.04.002)

Foord SM, Peters JR, Dieguez C, Jasani B, Hall R \& Scanlon MF 1984 Hypothyroid pituitary cells in culture: an analysis of thyrotropin and prolactin responses to dopamine (DA) and DA receptor binding. Endocrinology 115 407-415. (doi:10.1210/endo-115-1-407)

Heuer H, Ehrchen J, Bauer K \& Schafer MK 1998 Region-specific expression of thyrotrophin-releasing hormone-degrading ectoenzyme in the rat central nervous system and pituitary gland. European Journal of Neuroscience 10 1465-1478. (doi:10.1046/j.1460-9568.1998.00158.x) 
Heuer H, Schafer MK, O’Donnell D, Walker P \& Bauer K 2000 Expression of thyrotropin-releasing hormone receptor 2 (TRH-R2) in the central nervous system of rats. Journal of Comparative Neurology 428 319-336. (doi:10.1002/1096-9861(20001211)428:2<319::AID-CNE10>3.0. $\mathrm{CO} ; 2-9)$

Kadar A, Sanchez E, Wittmann G, Singru PS, Fuzesi T, Marsili A, Larsen PR, Liposits Z, Lechan RM \& Fekete C 2010 Distribution of hypophysiotropic thyrotropin-releasing hormone (TRH)-synthesizing neurons in the hypothalamic paraventricular nucleus of the mouse. Journal of Comparative Neurology 518 3948-3961. (doi:10.1002/cne.22432)

Kakucska I, Rand W \& Lechan RM 1992 Thyrotropin-releasing hormone gene expression in the hypothalamic paraventricular nucleus is dependent upon feedback regulation by both triiodothyronine and thyroxine. Endocrinology 130 2845-2850. (doi:10.1210/en.130.5.2845)

Larsen PR, Dick TE, Markovitz BP, Kaplan MM \& Gard TG 1979 Inhibition of intrapituitary thyroxine to $3,5,3^{\prime}$-triiodothyronine conversion prevents the acute suppression of thyrotropin release by thyroxine in hypothyroid rats. Journal of Clinical Investigation 64 117-128. (doi:10.1172/JCI109430)

Larsen PR, Silva JE \& Kaplan MM 1981 Relationships between circulating and intracellular thyroid hormones: physiological and clinical implications. Endocrine Reviews 2 87-102. (doi:10.1210/edrv-2-1-87)

Lechan RM \& Fekete C 2005 Role of thyroid hormone deiodination in the hypothalamus. Thyroid 15 883-897. (doi:10.1089/thy.2005.15.883)

Levy A, Matovelle MC, Lightman SL \& Young WS III 1992 The effects of pituitary stalk transection, hypophysectomy and thyroid hormone status on insulin-like growth factor 2-, growth hormone releasing hormone-, and somatostatin mRNA prevalence in rat brain. Brain Research 579 1-7. (doi:10.1016/0006-8993(92)90735-R)

Marsili A, Ramadan W, Harney JW, Mulcahey M, Castroneves LA, Goemann IM, Wajner SM, Huang SA, Zavacki AM, Maia AL et al. 2010 Type 2 iodothyronine deiodinase levels are higher in slow-twitch than fast-twitch mouse skeletal muscle and are increased in hypothyroidism. Endocrinology 151 5952-5960. (doi:10.1210/en.2010-0631)

Nikrodhanond AA, Ortiga-Carvalho TM, Shibusawa N, Hashimoto K, Liao XH, Refetoff S, Yamada M, Mori M \& Wondisford FE 2006 Dominant role of thyrotropin-releasing hormone in the hypothalamic-pituitarythyroid axis. Journal of Biological Chemistry 281 5000-5007. (doi:10.1074/ jbc.M511530200)

Pohlenz J, Maqueem A, Cua K, Weiss RE, Van Sande J \& Refetoff S 1999 Improved radioimmunoassay for measurement of mouse thyrotropin in serum: strain differences in thyrotropin concentration and thyrotroph sensitivity to thyroid hormone. Thyroid 9 1265-1271. (doi:10.1089/thy. 1999.9.1265)

Riskind PN, Kolodny JM \& Larsen PR 1987 The regional hypothalamic distribution of type II $5^{\prime}$-monodeiodinase in euthyroid and hypothyroid rats. Brain Research 420 194-198. (doi:10.1016/0006-8993(87)90260-5)
Sanchez E, Vargas MA, Singru PS, Pascual I, Romero F, Fekete C, Charli JL \& Lechan RM 2009 Tanycyte pyroglutamyl peptidase II contributes to regulation of the hypothalamic-pituitary-thyroid axis through glial-axonal associations in the median eminence. Endocrinology 150 2283-2291. (doi:10.1210/en.2008-1643)

Schneider MJ, Fiering SN, Pallud SE, Parlow AF, St Germain DL \& Galton VA 2001 Targeted disruption of the type 2 selenodeiodinase gene (DIO2) results in a phenotype of pituitary resistance to $\mathrm{T}_{4}$. Molecular Endocrinology 15 2137-2148. (doi:10.1210/me.15.12.2137)

Segerson TP, Kauer J, Wolfe HC, Mobtaker H, Wu P, Jackson IM \& Lechan RM 1987 Thyroid hormone regulates TRH biosynthesis in the paraventricular nucleus of the rat hypothalamus. Science 238 78-80. (doi:10. 1126/science.3116669)

Shupnik MA, Ridgway EC \& Chin WW 1989 Molecular biology of thyrotropin. Endocrine Reviews 10 459-475. (doi:10.1210/edrv-10-4-459)

Silva JE \& Larsen PR 1977 Pituitary nuclear 3,5,3'-triiodothyronine and thyrotropin secretion: an explanation for the effect of thyroxine. Science 198 617-620. (doi:10.1126/science.199941)

Silva JE \& Larsen PR 1978 Peripheral metabolism of homologous thyrotropin in euthyroid and hypothyroid rats: acute effects of thyrotropin-releasing hormone, triiodothyronine, and thyroxine. Endocrinology 102 1783-1796. (doi:10.1210/endo-102-6-1783)

Sugrue ML, Vella KR, Morales C, Lopez ME \& Hollenberg AN 2010 The thyrotropin-releasing hormone gene is regulated by thyroid hormone at the level of transcription in vivo. Endocrinology 151 793-801. (doi:10.1210/en. 2009-0976)

Tam SP, Lam KS \& Srivastava G 1996 Gene expression of hypothalamic somatostatin, growth hormone releasing factor, and their pituitary receptors in hypothyroidism. Endocrinology 137 418-424. (doi:10.1210/en.137.2.418)

Tu HM, Kim SW, Salvatore D, Bartha T, Legradi G, Larsen PR \& Lechan RM 1997 Regional distribution of type 2 thyroxine deiodinase messenger ribonucleic acid in rat hypothalamus and pituitary and its regulation by thyroid hormone. Endocrinology 138 3359-3368. (doi:10.1210/en.138.8. 3359)

Vale W, Burgus R \& Guillemin R 1968 On the mechanism of action of TRF: effects of cycloheximide and actinomycin on the release of TSH stimulated in vitro by TRF and its inhibition by thyroxine. Neuroendocrinology 3 34-46. (doi:10.1159/000121692)

Received in final form 15 July 2011

Accepted 25 July 2011

Made available online as an Accepted Preprint 25 July 2011 